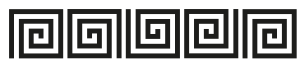

PHILOLOGIA CLASSICA
DE PHILOLOGIS

ET PHILOLOGIA
回回回|⿴囗口回

VOL. 13. FASC. 1. 2018

\title{
Friedrich Schiller and Gavriil Derzhavin in Greek: Translations by Christian Friedrich Graefe (1780-1851)
}

\author{
Elena L. Ermolaeva \\ St. Petersburg State University, \\ 7-9, Universitetskaya nab., St. Petersburg, 199034, Russian Federation; e.ermolaeva@spbu.ru
}

For citation: Elena L. Ermolaeva. Friedrich Schiller and Gavriil Derzhavin in Greek: Translations by Christian Friedrich Graefe (1780-1851). Philologia Classica 2018, 13(1), 165-180. https://doi.org/ 10.21638/11701/ spbu20.2018.113

Friedrich Graefe, the first Professor of Greek and Latin at the University of St Petersburg (1819-1851), a full member of the Imperial Academy of Sciences, teacher and friend of the famous Russian classicist and reformer S. S. Uvarov, belonged to the first generation of pupils studying in Leipzig under Gottfried Hermann. Following Hermann, Graefe expressed himself and wrote poetry in Latin and Ancient Greek. The list of his published Latin and Greek poetry (Gelegenheits-Schriften) can be found in the Bulletin of the Imperial Academy of Sciences, SPb. - Leipzig, 1852, 303-304. This article offers the first editions with a commentary of Ancient Greek translations by Graefe of the prologue to Friedrich Schiller's Bride of Messina (Die Braut von Messina oder die feindlichen Brüder) and the poem Modesty, by the Russian poet Gavriil Derzhavin (1743-1816). The article deals with the undated and probably unpublished manuscript which seems to be a small Greek anthology of eleven poems in various metres: iambic trimeter, dactylic hexameter, elegiac distich, Sapphic stanza, and the prose exhortation, written in the hand of Graefe and stored in the Manuscript Department of the Russian National Library in St Petersburg, among the papers of I. V. Pomyalovsky (1845-1906), a professor of classics at St Petersburg University. Graefe must have been encouraged to translate from Schiller by Hermann (who himself translated four parts from Schiller's Wallenstein trilogy) if not directly, at least by the example of his own translations.

Keywords: Graefe, Schiller, Bride of Messina, Derzhavin, translations in Ancient Greek, G. Hermann.

In this article, I offer first editions and a commentary on translations by Christian Friedrich Graefe of the prologue to Friedrich Schiller's Bride of Messina (Die Braut von Messina oder die feindlichen Brüder) and a poem by Gavriil Derzhavin Modesty into Ancient Greek. The undated manuscript, comprising seven sheets of poetry, clearly and

(C) St. Petersburg State University, 2018 
calligraphically written in the hand of Graefe on simple paper without watermark in brown ink, is housed at the Manuscript Department of the Russian National Library in St Petersburg, in the papers of I. V. Pomyalovsky (1845-1906), a professor of classics at St Petersburg University. ${ }^{1}$ The folder is entitled 'F. B. Graefe. ${ }^{2}$ His translation into Greek of an excerpt from Schiller's The Robbers, ${ }^{3}$ etc.'

\section{On the life of Graefe ${ }^{4}$}

Graefe was born in Chemnitz, Sachsen on 1 July (N.S.) 1780. At the age of seven, Graefe became a pupil at the Lyceum in Chemnitz. From 1799, he studied theology and philology at the University of Leipzig. Graefe belonged to the first generation of pupils studying in Leipzig under the great Gottfried Hermann (1772-1848). His fellows at that time included F. W. Thiersch, A. Seidler, B. G. Seidler, F. Hand, C. Linge and F. Passow. ${ }^{5}$ On 28 February 1805, Graefe became a doctor of philosophy (at that time in Leipzig he was called a Magister). ${ }^{6}$ After Graefe graduated from the university, he became a private tutor (Erzieher) and was later, in 1806, enlisted by Hermann to teach in Livonia for the family of Landrath Karl Gustav Samson von Himmelstjerna, the third daughter of whom, Hedwig, would later become Graefe's wife.

In 1810, on advice of Mikhail Speransky, Graefe arrived in St. Petersburg as a Professor of Greek at the Alexander Nevsky Theological Academy, founded in 1797. The following year, after Count Sergey S. Uvarov, superintendent of St Petersburg Educational District, had engaged him as a private tutor of Ancient Greek, Uvarov secured for him a position of a Professor of Latin and again, in 1815, of Greek at the Pedagogical Institute, a teacher training college founded in 1804. After the Pedagogical Institute was reorganized by Uvarov into the University of St Petersburg (1819), Graefe became its first Professor of Greek and then Latin, and, in 1829, that of Ancient Greek literature. In 1818, he became a corresponding member and, in 1820, a full member of the Imperial Academy of Sciences. From 1817 onward, by way of a bonus, he was made a custodian of the Collection of antiquities and coins in the Imperial Hermitage, a title later changed, in 1840, to Honorary Director of the Collection. From 1842, he was the active state councillor (deistvitelny statsky sovetnik).

Uvarov, following Wilhelm von Humboldt, who took lessons in Ancient Greek, engaged Graefe for the same purpose. Their remarkable privatissima ran three times a week for fifteen years uninterrupted except in cases for matters of the utmost urgency. ${ }^{7}$ Toward the end of his life, Uvarov wrote a memoir about Graefe, wherein he humorously recalled

1 RNL, MS department, F. 608, I, 4802.

2 In Russia, he went by the name Fyodor Bogdanovich Graefe.

3 This was obviously a mistaken identification.

4 Saltzwedel 20052, 173; Bursian 1879, 555-556; Schmid 1886, 77-108, 156-167; Verlinsky 2013, $162-$ 170; Smyshlyaeva 2015, 124-127.

${ }^{5}$ Graefe named his friends in the introduction of his Nonnus in 1819: "Atque his quidem subsidiis e patria mea maiore frui mihi hucusque licuit, augendis fortasse, si quid amicorum meorum, Seideri, Thierschii, Passovi, Weiskii, Handii, et Lingii, nondum, scio, extinctus in absentem amor de suis suppeditare non detrectaturus est." (Graefe 1819, VI).

6 The „Zeugnis“ by Hermann to Graefe is laudatory: "Si quis est eorum, qui mea disciplina utuntur, quem ob excellens ingenium, ob occuratam doctrinam, ob animi honestatem moresque cultissimos dilectum habeam, est is Christianus Fredericus Graefe..." (Schmid 1886, 161).

7 We know about this from their German correspondence: „Drei Mal in der Woche, heißt es in einem Briefchen, mit welchem diese Studien offenbar eingeleitet werden, sei er bereit zu arbeiten“ (Schmid 1886, 81). 
how, in the morning, Graefe was his subordinate, but, come evening, the roles were reversed, and he became a mere pupil. ${ }^{8}$ Uvarov wrote that Graefe once told him the following: "It is unfortunate that you became a minister. You might otherwise have become a good Greek scholar, but in that case you would have had to pay more attention to Greek grammar, since you do not hold it in sufficiently high regard."

During their privatissima the two read Homer, Aeschylus, Sophocles, Aristophanes, Demosthenes, and poets of the Anthologia Palatina. ${ }^{10}$ The common interest of Uvarov and Graefe was in Greek literature from Late Antiquity, the period of transition from paganism to Christianity.

Graefe's own strong points were in the field of textual criticism and linguistics, to the extent that Hermann even proposed that Graefe should edit the Dionysiaca by Nonnus of Panopolis. He supported Graefe by providing books, arranging a contract with the Vogel Publisher House in Leipzig and reading proofs. ${ }^{11} \mathrm{He}$ urged Graefe on, fearing that his rivals might be working on the same text. ${ }^{12}$ Finally, in 1819 , the first volume of the critical edition of Nonnus appeared, followed, in 1826, by the second. Curiously, Uvarov edited his own Nonnos von Panopolis der Dichter, written in German, which he had dedicated to Goethe two years earlier, in 1817. This edition was the result of Uvarov and Graefe having read Dionysiaca entirely through together. In his book, Uvarov wrote about the style and prosody of Nonnus. We know from Schmid that Graefe had prepared not only the critical edition but also his commentary to Nonnus, but the publisher rejected the commentary because of the immense bulk it would have added to the book. From Uvarov's book, however, one can discern a distinct style of Graefe to the commentaries on Nonnus, as Uvarov had put pieces of Graefe's translations and commentaries into his own book, with references to his teacher.

On 12 December 1851, in St. Petersburg, Graefe passed away and was buried at the Smolensky Lutheran cemetery (Der Deutsche Evangelisch-Lutherische SmolenskiFriedhof).

\section{The Manuscript in the RNL}

Following Hermann, ${ }^{13}$ Graefe habitually expressed himself in Latin and Greek, writing poetry on occasions captandae benevolentiae causa. ${ }^{14}$ Professor Georg Schmid wrote:

8 Uvarov $1852,46$.

9 Uvarov $1852,50$.

10 At that time, Graefe edited: Meleagri Gadareni epigrammata, tamquam specimen novae recensionis Anthologiae Graecae cum observationibus criticis. Leipzig, 1811; Epistola critica in Bucolicos Graecos ad S. Uvaroff. SPb., 1815; Observationes criticae in Tryphiodorum. SPb., 1817; Conjecturae in Coluthum et Museum. SPb., 1818.

11 Graefe 1819, IX.

12 Schmid $(1886,89)$ cited Hermann's letter of 13 June 1809: „Hofrath Beck hat zwar vor wenig Tagen zu Lobecken gesagt, dass der Nonnus bald dran kommen sollte: aber Sie wissen ja, was das heisst. Jetzt lässt er an dem Aristophanes drucken, und wenn Sie daher in aller Stille Ihre Sache machen, so erscheint Ihr Buch auf jeden Fall eher als sein Nonnus".

13 Wilamowitz ${ }^{3} 1998,49$.

14 Uvarov's letters to Graefe of 25 August 1818: „Sonntag ist mein Geburtstag. Sie müssen den ganzen Tag bei mir auf dem Lande zubringen..." Gewiss ist Graefe nicht ohne das Xenion einer griechischen Elegie erschienen, wie sich deren mehrere auf das Wiegenfest seines Gönners gedichtete erhalten haben" (Schmid 1886, 85). 
„...Hermann sagt, wenn ihm einer seiner Schüler wegen seines ausgezeichneten Talentes, seines soliden Wissens, seiner edlen Denkweise und seiner Bildung lieb und wert sei, so sei dies Gräfe... Er habe sich auch eine seltene Kenntnis des Griechischen und Lateinischen, die innigste Vertrautheit mit den alten Schriftstellern und großes Geschick in Kritik erworben. Griechisch insbesondere schreibe er nicht bloß in Versen und in Prosa aufs eleganteste, er besitze auch eine seltene Fertigkeit es zu sprechen und griechisch zu disputieren."15

The following is a list of Graefe's published Latin and Greek poetry (GelegenheitsSchriften): ${ }^{16}$

1. Gallorum sub Brenno in Graecia clades et infamia nostris temporibus in memoriam revocata. MDCCCXII. 8. 10 S. 2. ҮMNO $\Sigma$ EI $\Sigma$ NEME $\Sigma$ IN EN THI NIKHI KAI T $\Omega$ I NO $\Sigma T \Omega I$ A $\Lambda E \Xi A N-$ $\triangle$ POY TOY $\Sigma$ EBA $\Sigma T O Y$. Hymne à Némésis à l’occasion du triumphe et du retour de Sa Majesté l'Empereur. Par le Dr. F. Graefe. St.- Pétersbourg. 1814. 4. 25 pp. ${ }^{17}$

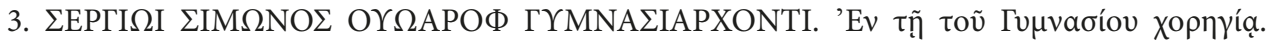
MDCCCXVI. 4. 25.

4. Ad imaginem Alexandri I. imperatoris et auctoris omnium Rossorum in museo numismatico Imp. Academiae Scient. Petropoli positam Cal. Mart. MDCCCXXIV. Fol. 2 S.

5. THI KAI $\Sigma$ APEIAI ПEPI EПI $\Sigma$ THM $\Omega N$ AKA $\triangle$ HMIAI THI EN ПETPO $\Pi$ ПO $\Lambda$ EI THN

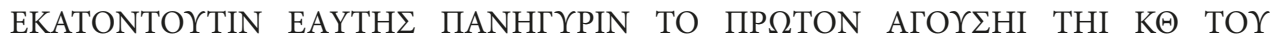
$\triangle$ EKEMBPIOY TOY A $\Omega$ KФ (A $\Omega$ KC? - EE) ETOY $\Sigma$. Fol. 20 S. Der Kaiserlichen Akademie der Wissenschaften zu St. Petersburg bey ihrer ersten Saecular-Feier den XXIX. December MDCCCXXVI. Für wenige aus dem Griechischen übersetzt vom Verfasser. 4. 22 S.

6. H KI $\Omega$ N TOY АГГЕ $\Lambda$ Y. THI A MHNO $\Sigma$ AҮГOҮ $\Sigma$ TOY ETOY $\Sigma$ A $\Omega \Lambda \Delta .4 .4$ Bl. ${ }^{18}$

7. Imperatori Augustissimo Domino suo Clementissimo quid pro tot ac tantis beneficiis Universitas Literaria debeat? Oratio in solemni Universitatis inauguratione habita a Fr. Graefo. Petropoli MDCCCXXXVIII. 8. 16 S.

The Greek verses in the manuscript at hand were most probably composed by Graefe - who else in Russia at that time could have written in Ancient Greek? The text seems to be a small Greek anthology of eleven poems in various metres: iambic trimeter, dactylic

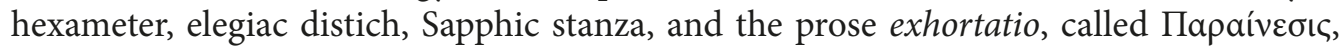
finishing this manuscript with an appeal to a young figure, $\tilde{\omega} v \varepsilon a v i ́ a$, and a piece of advice

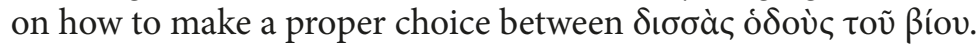

The manuscript starts with a translation of the prologue of Schiller's Bride of Messi$n a-$ the first 46 verses of Isabella's speech, written in Ancient Greek in iambic trimeter. The following is an edition of this translation; I put accents absent in Graefe's manuscript ${ }^{19}$ and normalize his punctuation with respect to modern conventions by erasing superfluous comas (as in vv. 16, 20, 21; for Graefe's autograph see the photos); I further provide an apparatus criticus and commentary.

15 Schmid 1886, 80 .

16 The Bulletin of the Imperial Academy of Sciences, SPb. - Leipzig, 1852, 303-304.

17 Graefe wrote to Hermann: "Hier geht es uns privatim ganz leidlich, ausser den ungeheuern Lasten und Abgaben, die wir, um allerley Fremde fett $\mathrm{zu}$ machen, tragen mussten. Oeffentlich desto schlechter, da Sie wohl denken können, wie uns zu Muthe ist. Indessen hoffen wir alle auf die Nemesis” (Schmid 1888, 85).

$18 \mathrm{H} \mathrm{KI} \Omega \mathrm{N}$ TOY АГГЕ $\Lambda \mathrm{O} \Upsilon$ is the Alexandrian Column erected at the Palace Square by August de Montferrand in $\mathrm{A} \Omega \Lambda \Delta 1834$ to the Emperor Alexander I after his victory over Napoleon.

19 Graefe was not an exception. Stefan Weise, in his profound study on Neohellenistic literature in Germany, noticed, as he puts it, that „Ein Kuriosum am Ende des 18. und Anfang des 19. Jhs. sind bisweilen griechische Texte, die völlig auf Akzente verzichten“ (Weise 2016, 124). 
Fr. Schiller. Die Braut von Messina oder

die feindlichen Brüder.

Ein Trauerspiel mit Chören. Über den Ge-

brauch des Chors in der

Tragödie. 1803. ${ }^{20}$

Erster Auftritt.

Donna Isabella in tiefer Trauer,

die Ältesten von Messina stehen um sie her.

\section{Isabella}

1 Der Noth gehorchend, nicht dem eignen Trieb,

2 Tret' ich, ihr greisen Häupter dieser Stadt,

3 Heraus zu euch aus den verschwiegenen

4 Gemächern meines Frauensaals, das Antlitz

5 Vor euren Männerblicken zu entschleiern.

6 Denn es geziemt der Wittwe, die den Gatten

7 Verloren, ihres Lebens Licht und Ruhm,

8 Die schwarz umflorte Nachtgestalt dem Aug

9 Der Welt in stillen Mauern zu verbergen;

10 Doch unerbittlich allgewaltig treibt

11 Des Augenblicks Gebieterstimme mich

12 An das entwohnte Licht der Welt hervor

13 Nicht zweimal hat der Mond die Lichtgestalt

14 Erneut, seit ich den fürstlichen Gemahl

$15 \mathrm{Zu}$ seiner letzten Ruhestätte trug,

16 Der mächtigwaltend dieser Stadt gebot,

17 Mit starkem Arme gegen eine Welt

18 Euch schützend, die euch feindlich rings umlagert.

19 Er selber ist dahin, doch lebt sein Geist

20 In einem tapfern Heldenpaare fort

21 Glorreicher Söhne, dieses Landes Stolz.

$22 \mathrm{Ihr}$ habt sie unter euch in freud'ger Kraft

23 Aufwachsen sehen, doch mit ihnen wuchs

24 Aus unbekannt verhängnisvollem Samen

25 Auch ein unsel'ger Bruderhaß empor,

26 Der Kindheit frohe Einigkeit zerreißend,

27 Und reifte furchtbar mit dem Ernst der Jahre.

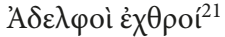

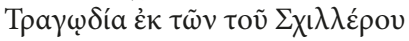

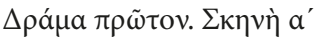

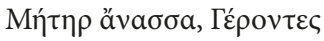

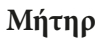

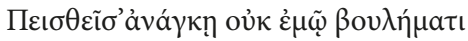

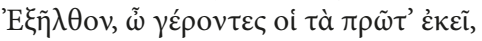

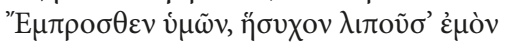

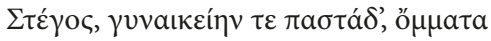

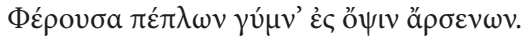

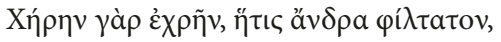

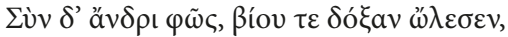

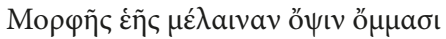

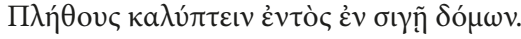

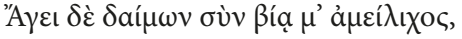

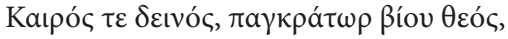

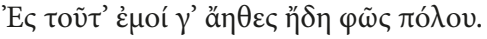

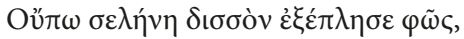

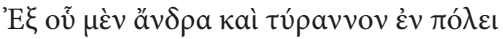

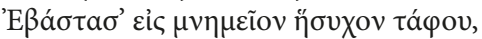

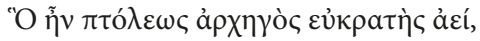

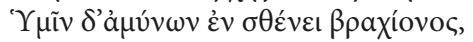

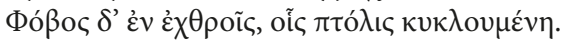

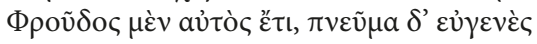

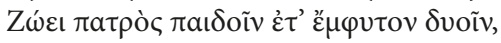

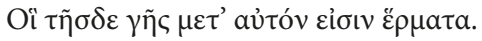

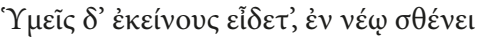

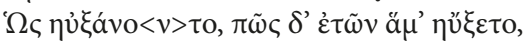

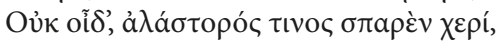

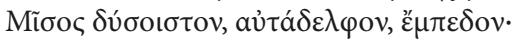

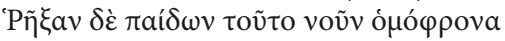

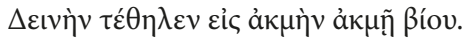

20 Schiller (1803, XIV) included the following introduction about the chorus in his tragedy: „Soviel über meine Befugniß, den alten Chor auf die tragische Bühne zurückzuführen. Chöre kennt man zwar auch schon in der modernen Tragödie; aber der Chor des griechischen Trauerspiels, so wie ich ihn hier gebraucht habe, der Chor als eine einzige ideale Person, die die ganze Handlung trägt und begleitet, dieser ist von jenen opernhaften Chören wesentlich verschieden, und wenn ich bei Gelegenheit der griechischen Tragödie von Chören statt von einem Chor sprechen höre, so entsteht mir der Verdacht, daß man nicht recht wisse, wovon man rede. Der Chor der alten Tragödie ist meines Wissens seit dem Verfall derselben nie wieder auf der Bühne erschienen. Ich habe den Chor zwar in zwei Theile getrennt und im Streit mit sich selbst dargestellt; aber dies ist nur dann der Fall, wo er als wirkliche Person und als blinde Menge mithandelt. Als Chor und als ideale Person ist er immer eins mit sich selbst. Ich habe den Ort verändert und den Chor mehrmal abgehen lassen; aber auch Aeschylus, der Schöpfer der Tragödie, und Sophokles, der größte Meister dieser Kunst, haben sich dieser Freiheit bedient."

${ }^{21}$ Graefe only translated the subtitle of Schiller's play die feindlichen Brüder perhaps to avoid the specific allusion to Messina in favour of the more ancient-sounding enemy brothers. 
28 Nie hab' ich ihrer Eintracht mich erfreut;

29 An diesen Brüsten nährt' ich beide gleich,

30 Gleich unter sie vertheil' ich Lieb' und Sorge,

31 Und beide weiß ich kindlich mir geneigt.

32 In diesem einz'gen Triebe sind sie Eins,

33 In allem Andern trennt sie blut'ger Streit.

34 Zwar, weil der Vater noch gefürchtet herrschte,

35 Hielt er durch gleiche Strenge

36 Gerechtigkeit die Heftigbrausenden im Zügel,

37 Und unter eines Joches Eisenschwere

38 Bog er vereinend ihren starren Sinn.

39 Nicht waffentragend durften sie sich nahn,

40 Nicht in denselben Mauern übernachten.

41 So hemmt' er zwar mit strengem Machtgebot

42 Den rohen Ausbruch ihres wilden Triebs;

43 Doch ungebessert in der tiefen Brust

44 Ließ er den $\mathrm{Haß}$ - der Starke achtet es

45 Gering, die leise Quelle zu verstopfen,

46 Weil er dem Strome mächtig wehren kann.

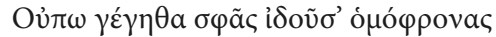

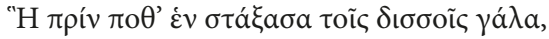

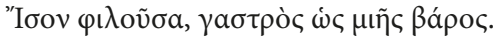

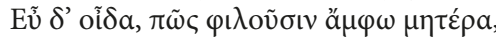

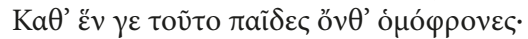

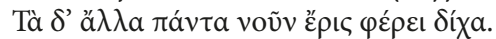

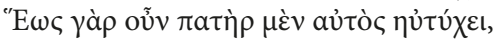

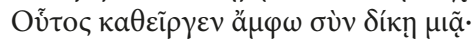

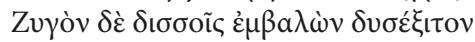

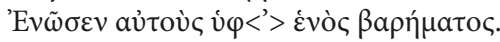

?

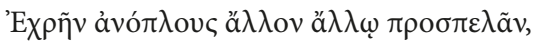

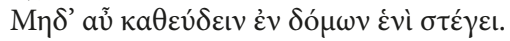

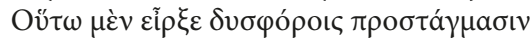

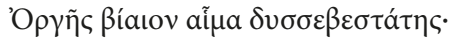

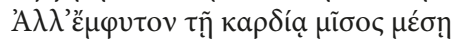

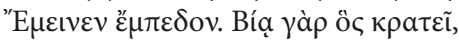

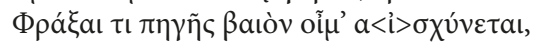

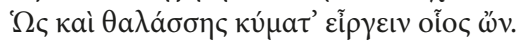

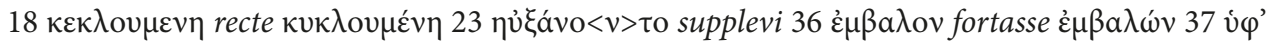

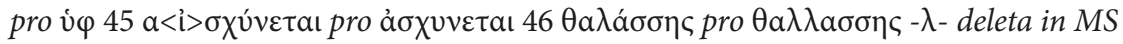

\section{Commentary}

4. It is worth noticing that Graefe used to write the ligature $\zeta$ for $\sigma \tau$ along with $\sigma \tau$ : e.g.,

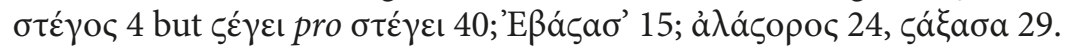

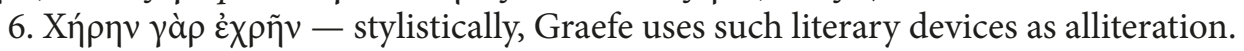

8. $\varepsilon \tilde{\eta} \varsigma$ - Ionian form.

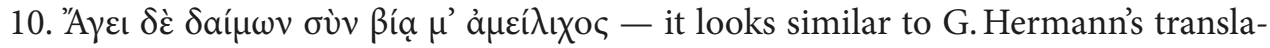

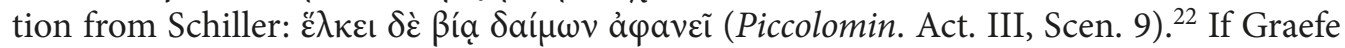
followed Germann here, it would probably explain why he used the Attic form ßía along with the Ionian $\mu$ iñ 30 .

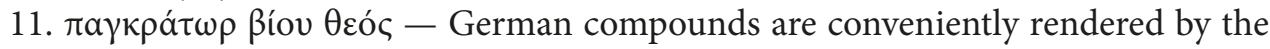

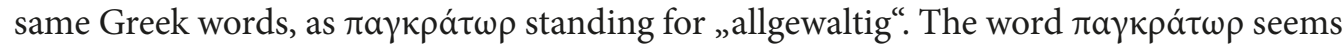
to be late; it is attested e.g. in Isidorus Hymn. 4, 23; Greg. Naz. Christus patiens 1339; the

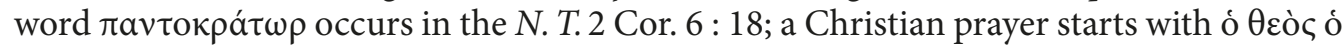

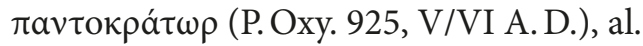

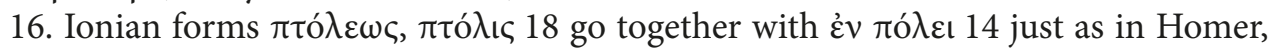

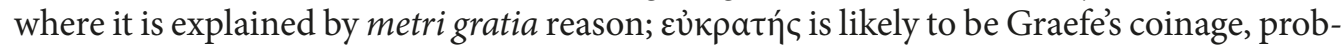
ably equal to $\dot{\varepsilon} \gamma \kappa \rho \tau \tau$ ́ $\varsigma=$,in seiner Gewalt habend“ (Passow).

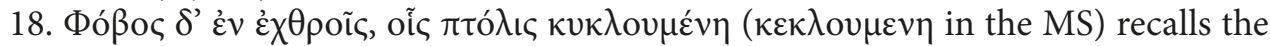

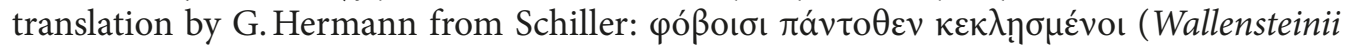
Morte Act. IV, Scen. 10); ${ }^{23}$ that seems to explain a mistake in Graefe's MS.

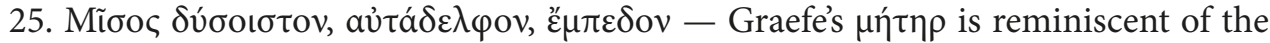
mother of Eteocles and Polynices (cf. the Iocasta by Göller, on which see below); some-

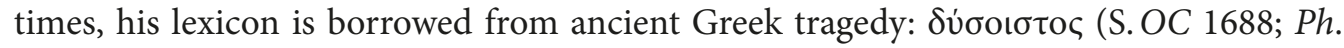

22 Thiersch 1820, 145; Hermann 1834, 357.

23 Thiersch 1820, 146; Hermann 1834, 358. 


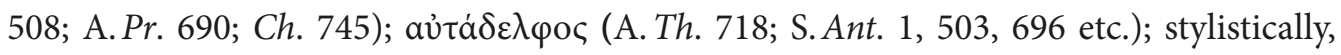

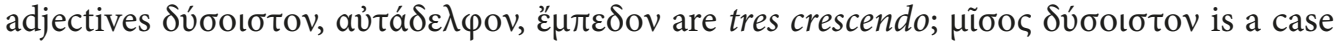
of [s] alliteration;

26. óóppova - two more times in the same position at the end of the verse:

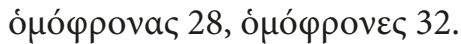

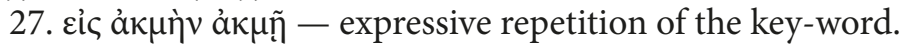

30. Ionian $\mu$ iñ appears along with $\mu$ iã 35 .

32. ỏv $\theta^{\prime}=$ óv $v \varepsilon$.

35 . In the word ä $\mu \varphi \omega$ long syllable - $\varphi \omega$ - stays in place of shot in the iambic trimeter.

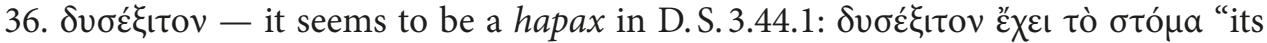
mouth is... hard to get out of" (tr. C. H. Oldfather 1979, 216).

38. One verse went missing in the translation (there are 45 Greek lines versus 46 German ones).

39. $\pi \rho \circ \sigma \pi \varepsilon \lambda \tilde{\alpha} \nu$ - probably in the sense of $\pi \rho \circ \sigma \pi \varepsilon \lambda a ́ \zeta \varepsilon เ v$ which is contra metrum here; the verb $\pi \rho \circ \sigma \pi \varepsilon \lambda \tilde{\alpha} v$ is not found in the Corpus of the TLG.

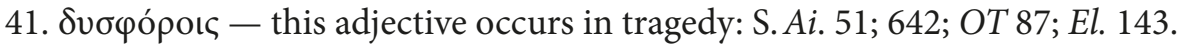

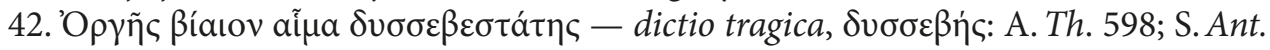
514.

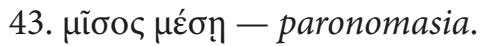

46. oĩoৎ $\ddot{\omega} v-$ more frequently: oî́ó $\tau$ ' $\ddot{\omega} v$.

Resolutions do not occur in Graefe's iambic trimeter. Porson's Law is broken four

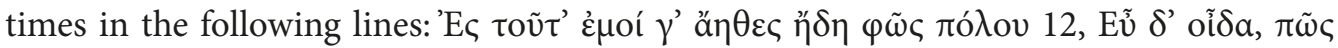

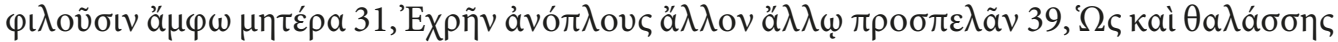

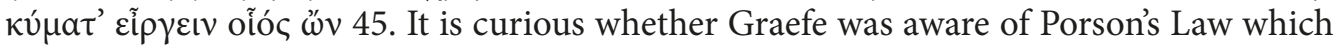
was formulated in $1802 .{ }^{24}$

\section{When and where did Graefe make this translation?}

The premiere of the Bride of Messina was on 19 March 1803, in Weimar. At that time, Graefe was a student of Hermann in Leipzig. Schiller's attempt to reconstruct the form of ancient tragedy (reminiscent of the tragedy of Eteocles and Polynices) might even have been a matter of discussion at Hermann's 'Greek society'. In theory, then, Graefe could have been inspired already at that time.

Graefe could translate Schiller when he was in the presence of Hermann, who himself translated four parts from Schiller's Wallenstein trilogy (1799). ${ }^{25}$ Thus, he certainly must have encouraged his students to do the same - if not directly, at least by the example of his own translations. ${ }^{26}$ How Hermann estimated this tragedy and why he translated Schiller into Ancient Greek we learn from his letter to Thiersch:

"Quum ante hos viginti annos edito in lucem Schilleri Wallensteinio vehementer commota essent nostratium studia, saepe me dicere memini, sensisse Schillerum, in quibus rebus posita esset natura Graecae tragoediae, sed, quoniam non perspexisset, non satis vitasse vitia recentiorum.

${ }^{24}$ Porson R. Supplementum ad Praefationem ad Hecubam, 1802, XXX.

25 Piccolomini, Act 3, Scene 9; Wallenstein's Tod, 1, 7; 4, 10, 12 (Hermann 1834, 355-361).

${ }^{26}$ My thanks go to Stefan Weise for the insightful discussion on this subject, for sending me his article

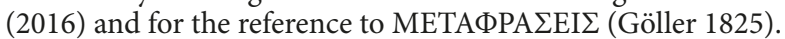




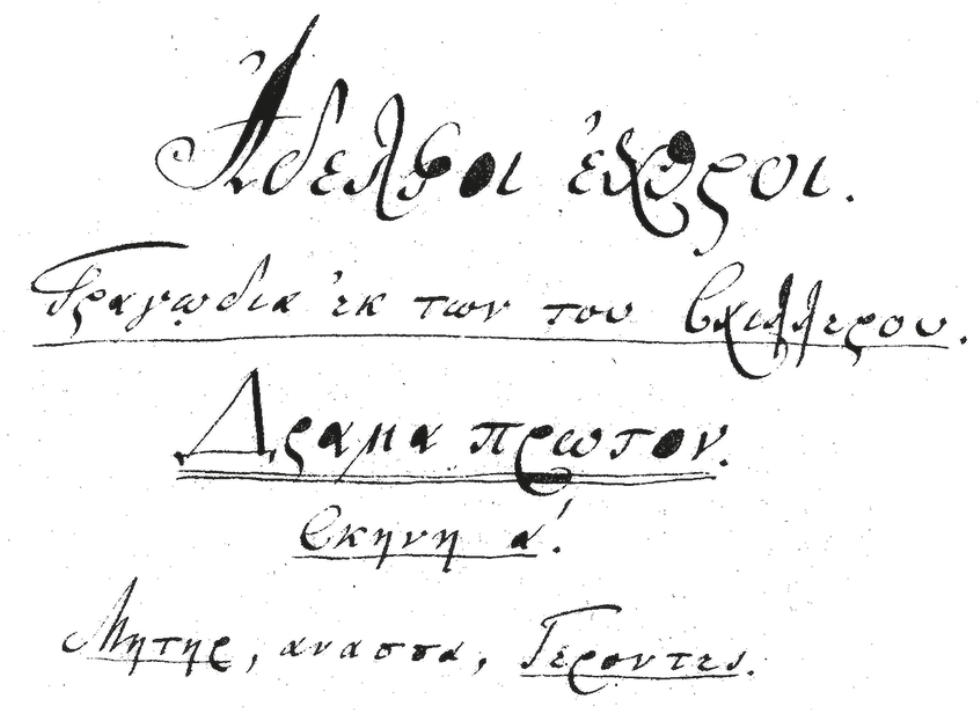

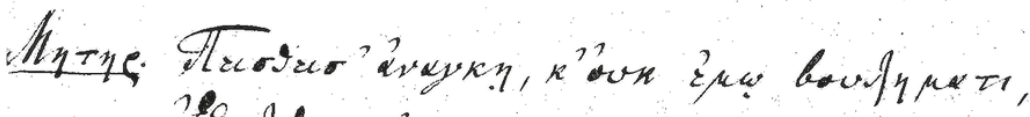

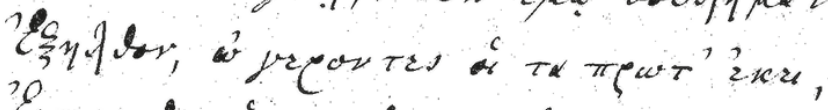

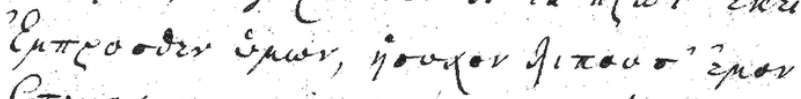

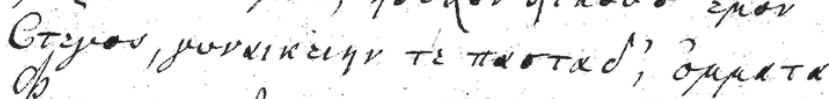

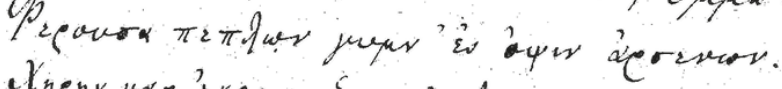

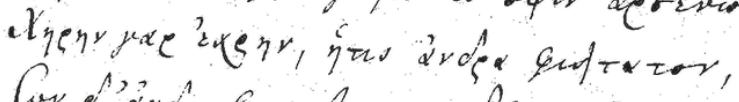

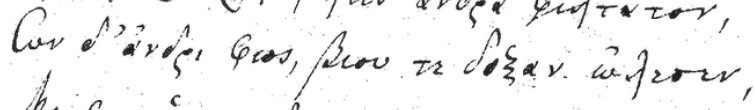

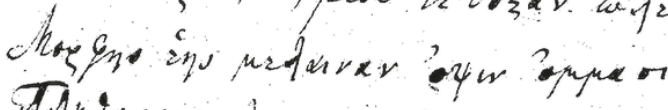

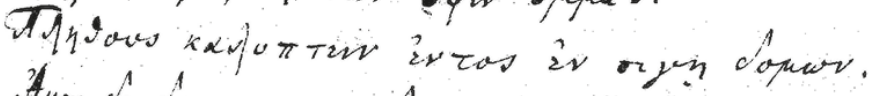

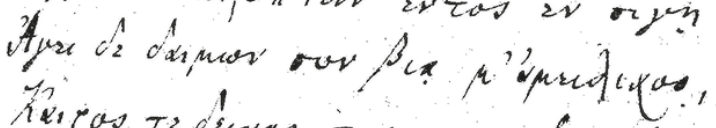

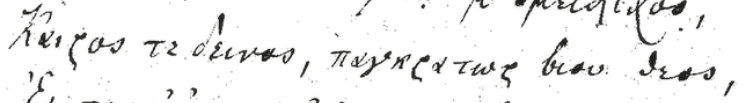

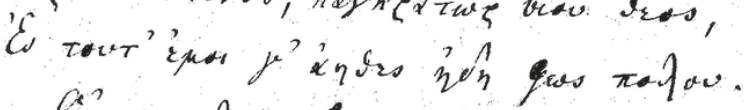

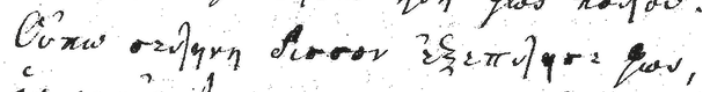

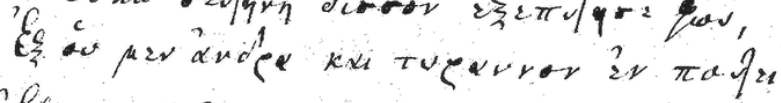

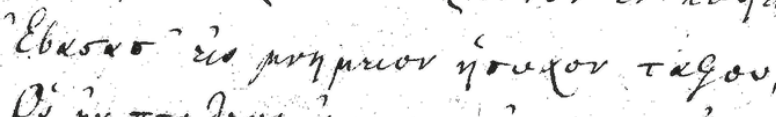

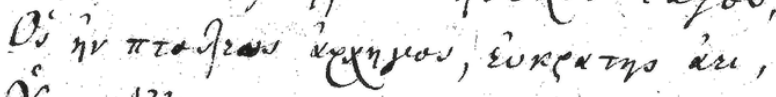

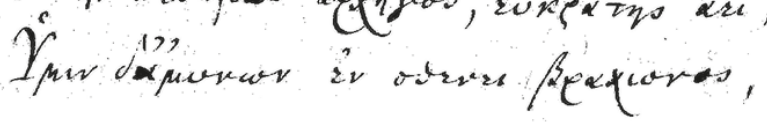




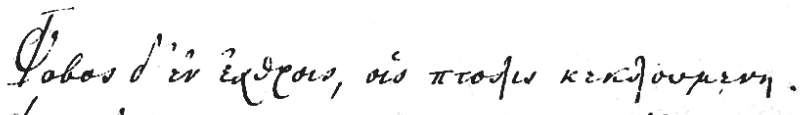

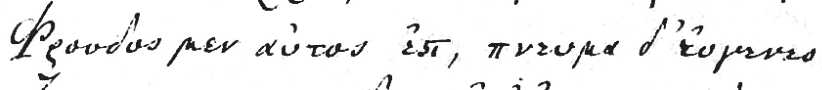

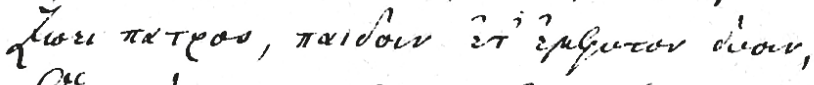

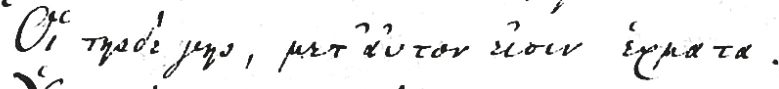

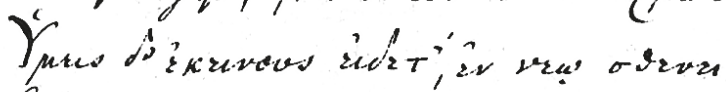

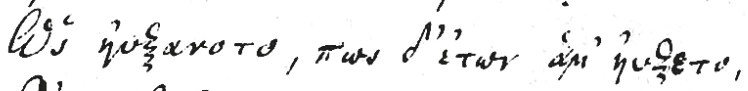

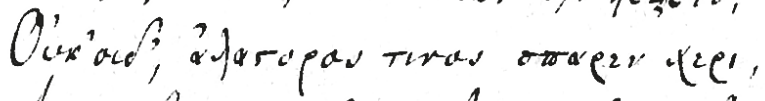

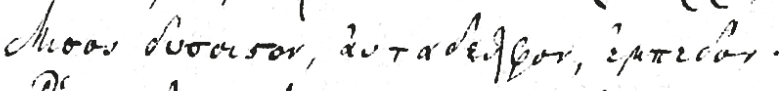

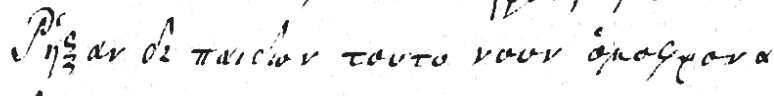

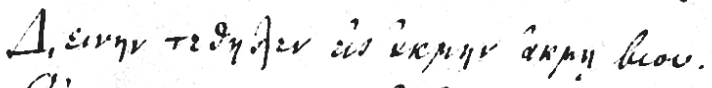

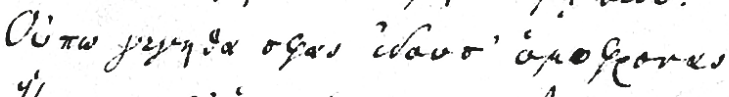

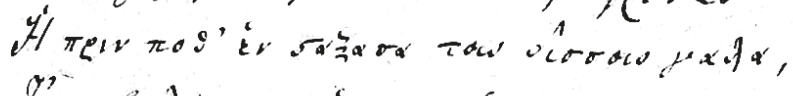

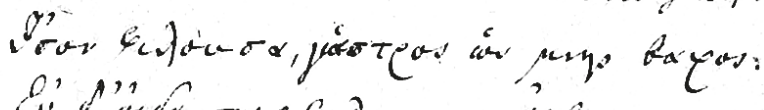

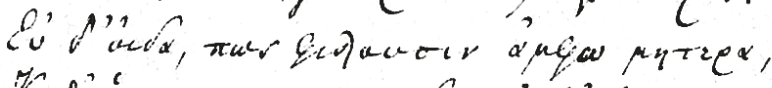

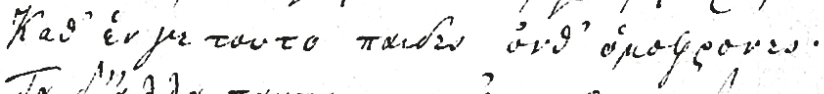

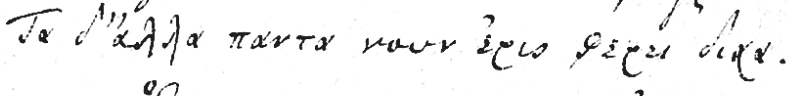

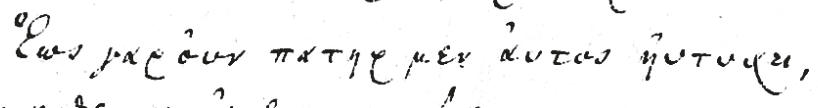

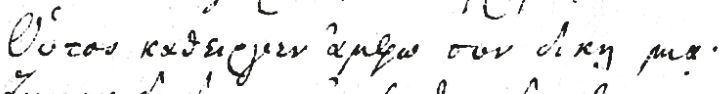

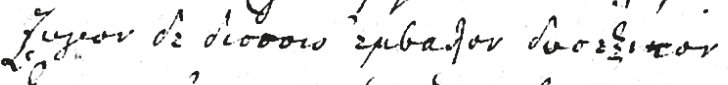

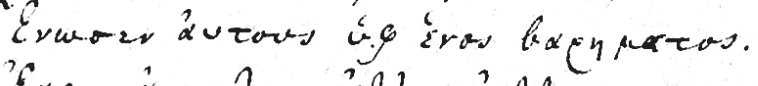

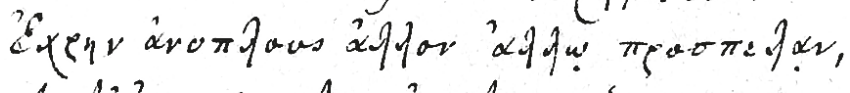

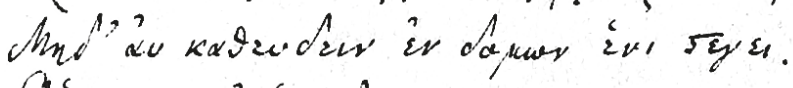

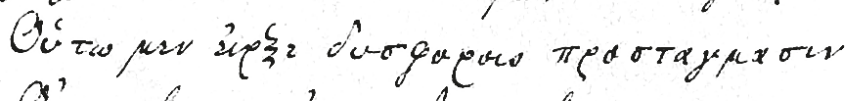

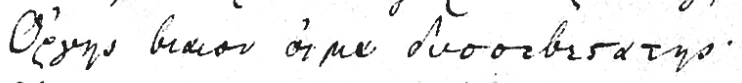

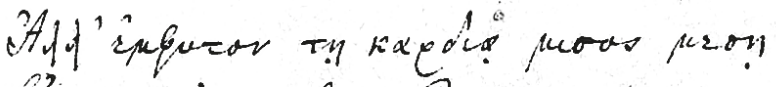

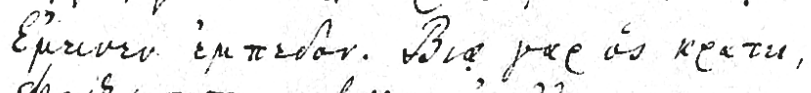

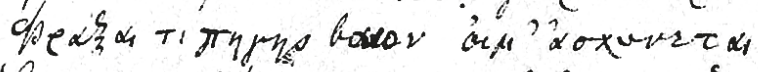

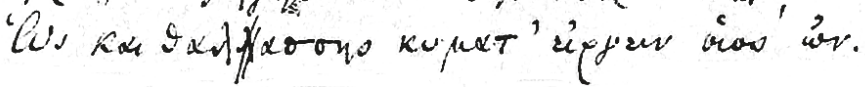




\section{Crponretions.}

Tuxin, number bromeporuxt havb nopureuc mb нa trodesty

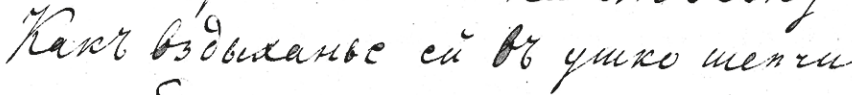

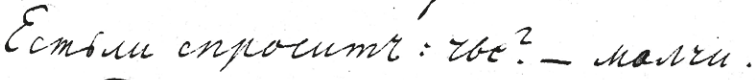

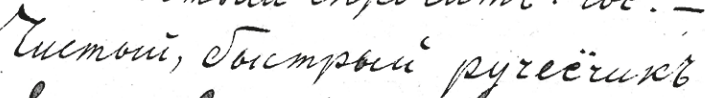
Combun bemptmumb mor drociesty,

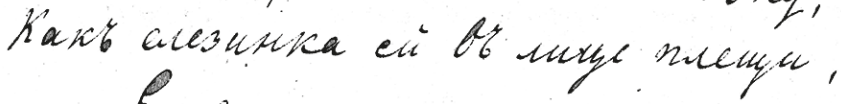
Eombu inpacunz: vbe? - havew.

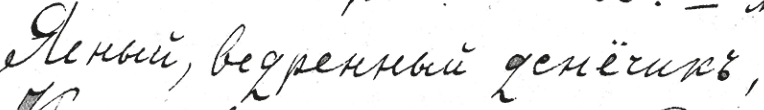

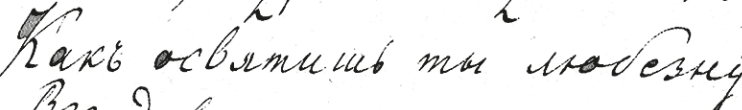

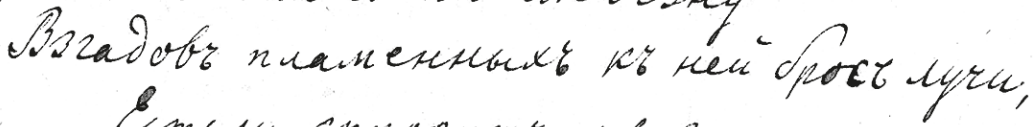

Tensiai, nupmobbi Atcoun?,

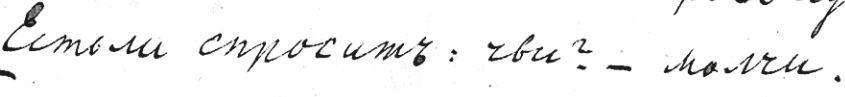
haxt coxporut mbe tradeztly,

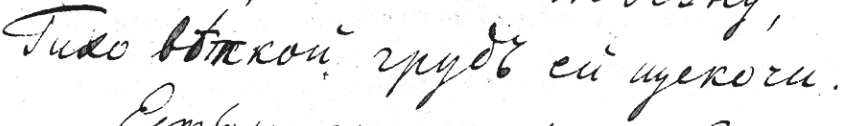
Combur cnposumb: kmo? - hoten.

Arportaturt. 


\section{Cypy Ewas:}

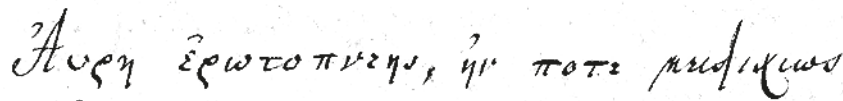

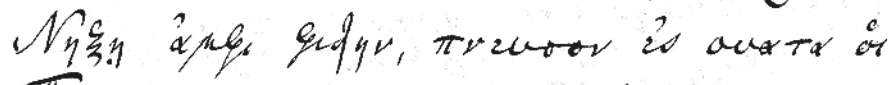

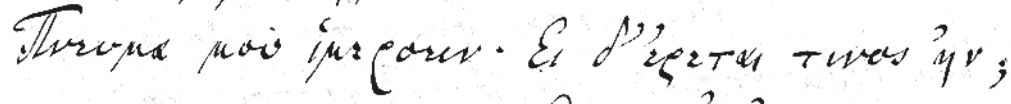

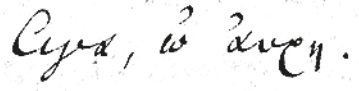

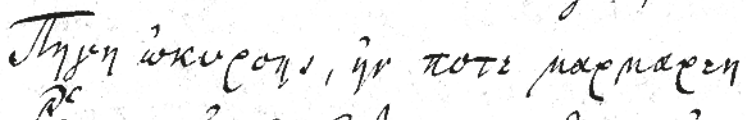

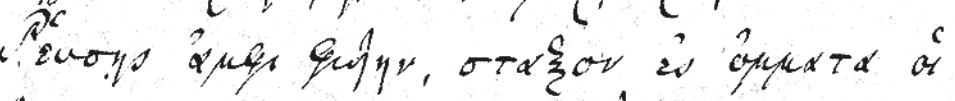

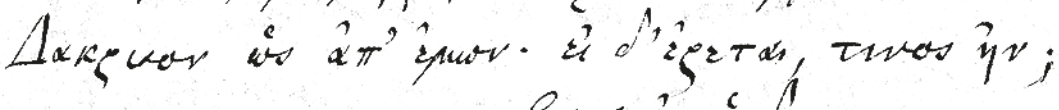

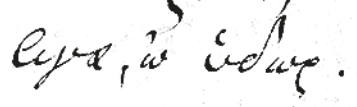

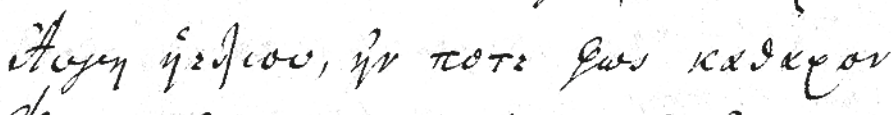

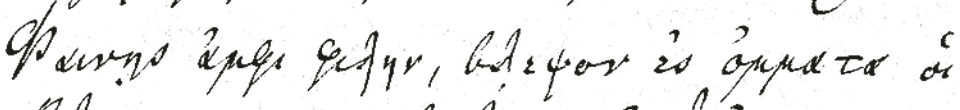

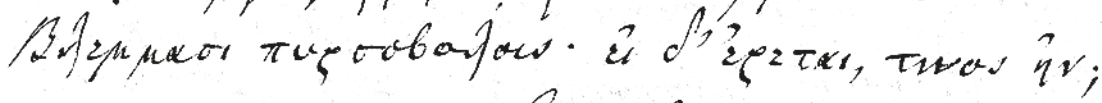

$$
\text { laja, w ixayn. }
$$

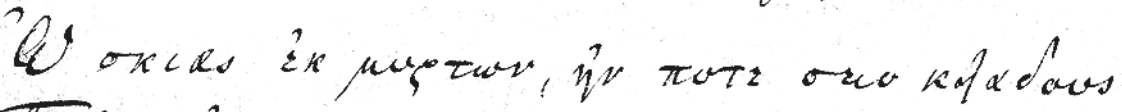

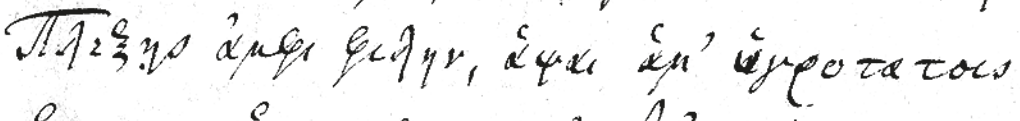

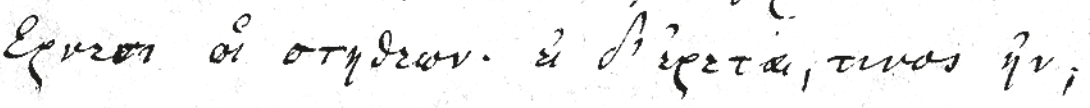
Ciya, is ipras.

Fig. C. F. Graefe's manuscript (RNL, MS department, F.608, I, 4802), showing his translation of the prologue to Friedrich Schiller's Bride of Messina into Ancient Greek, and a poem by Gavriil Derzhavin Modesty in Russian and Greek. 
Neque exordium facere, nec finire fabulam scivisse; ingenti numero personarum introducendo nocuisse simplicitati illi, in qua maxima cerneretur laus tragoediae; multa etiam in singulis partibus admisisse, quae a gravitate tragoediae plane essent aliena; caeterum plurima esse talia, ut, si graece scripta essent, graeco tragico non possent non haberi dignissima. ... Videbis autem, quaedam, quae non satis accommodata ad gravitatem tragoediae scripserat Schillerus, mutata esse ad exemplum Graecorum, veluti centurionis ad Theclam introducti indecoram trepidationem." ${ }^{27}$

Graefe could thus have translated the prologue to the Bride of Messina just after the premiere of the play in Weimar and following a broad discussion of Schiller's controversial experiment with his chorus in modern society.

At a broader level, the burgeoning of Neo-Latin and Ancient Greek translations was a feature of the time, the golden age of classical scholarship - not only Vergil and Horatius but also German classical poets like Goethe and Schiller were translated into Ancient Greek. $^{28}$ In 1825, Franz Göller (1790-1853) published the METAФPA $\Sigma E I \Sigma$, an anthology of Ancient Greek translations of Vergil, Horatius, Claudianus, Goethe and Schiller by Gottfried Hermann, Friedrich Thiersch, Friedrich Jakobs, Franz Xaver Werfer, Robert Porson and the editor himself. ${ }^{29}$ In the volume, Göller also published his own translation of the first 100 verses of the prologue from the Bride of Messina in iambic trimeter; his

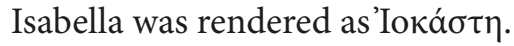

Graefe's and Göller's translations have similar features, e. g., the beginning of the

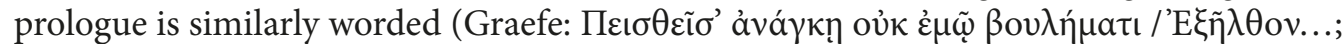

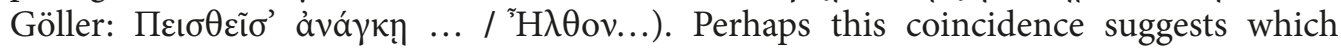
translation came first. Graefe could have read Göller's translation of Schiller in the METAФPA $\Sigma E I \Sigma$, which Hermann certainly would have sent him. By that time, when the second volume of his opus magnum, his edition of Nonnus, was nearing completion, Graefe had become rather gregarious, and his contacts with Hermann, which had never been interrupted, were especially active.

Graefe could hardly have been inspired to translate the prologue sometime after the premiere of the Bride of Messina, translated into Russian by Alexander G. Rotchev (18061873 ) in 1829 , which took place in $1840-41{ }^{30}$ Graefe almost certainly did not know that in 1805, Sigismund von Neukomm (1778-1858), a Kapellmeister at St Petersburg German theatre (1804-1808), completed his melodrama based on Schiller's tragedy Die Braut von Messina. $^{31}$

27 Göller 1825, IV-V. First published in the Anthologia carminum Graecorum by F. Thiersch in the Acta Philologorum Monacensium, III, 1 (1820). According to G. Hermann himself, the letter was written "a. 1820" (Hermann 1834, 355).

${ }_{28}$ Weise (2016, 121-123); Wöhrle 2016, 77-81; see especially Richtsteig 1927.

${ }^{29}$ Göller 1825.

30 On Schiller in Russia in the late 18th and early 19th centuries, see Lotman 1958/59, 419-434; Danilevskij 1998.

31 Recently, in the library of the Duchess Anna Amalia in Weimar, Denys Germanovič Lomtev discovered a rare manuscript of Neukomm's Die Braut von Messina never performed during Neukomm's life. See Deutsche Allgemeine Zeitung, Almaata Kazachstan, 24 Okt. 2008, 3:http://wolgadeutsche.net/rd/pdf/ DAZ_Runde_Lomtew.pdf (03.03.2017).

Perhaps Graefe could have known about other musical interpretations of Schiller's tragedy: for instance, the opera La sposa di Messina by Nicola Vaccai, which premiered in 1839, and R. Schumann's overture to Die Braut von Messina, Opus 100 (1850-1851). 
On pages 8-9 of the manuscript there is the poem Modesty (Skromnost, 1791-1795) by Gavriil Derzhavin (1747-1816), recorded by Graefe in Russian alongside with Greek translation:

\section{Г. ДЕРЖАВИН. СКРОМНОСТЬ ${ }^{32}$}

Gavriil Derzhavin 'Modesty'

Тихий, милый ветерочик, Коль порхнешь ты на любезну, Как вздыханье ей в ушко шепчи. Естьли спросит: чье? - молчи.

5 Чистый, быстрый ручеёчик, Естьли встретишь ты любезну, Как слезинка ей в лицо плещи. Естьли спросит: чье? - молчи.

Ясный, ведренный денёчик,

10 Как освятишь ты любезну, Взглядов пламенных ей брось лучи. Естьли спросит: чьи? - молчи.

Темный, миртовый лесочик, Как сокроешь ты любезну,

15 Тихо веткой грудь ей щекочи. Естьли спросит: кто? - молчи.

Wind sweet-blowing and gentle, If thou blow upon my darling, Breathe a whisper in her ear. Soft thou be if asked, 'who's here?'

Rivulet swift-flowing and clear, If thou come upon my darling, Spray her face as if with tear. Soft thou be if asked, 'who's here?'

Morning bright and bathed in sunlight, When thou shine upon my darling, Eye her sending shafts of fire.

Soft thou be if asked, 'who's here?'

Woodland dark and myrtle-grown, When thy shade falls on my darling, Touch her bosom swishing near. Soft thou be if asked, 'who's here?'

(Tr. Tatiana Kostyleva, 2018)

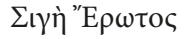

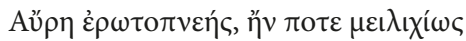

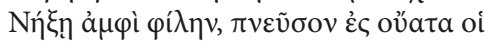

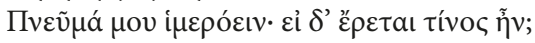

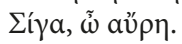

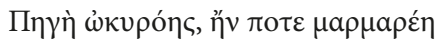

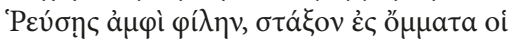

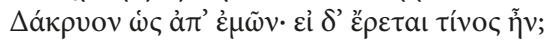
$\Sigma i ́ \gamma \alpha, \tilde{\omega} \cup \tilde{\delta} \delta \rho$.

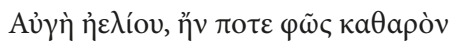

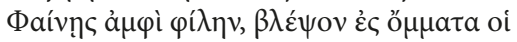

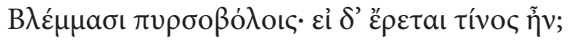

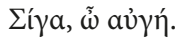

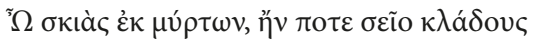

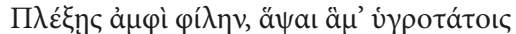
"Е

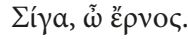

\footnotetext{
32 I preserve Graefe's Russian text as it is in his manuscript, and I put accents in his Greek.
} 
Graefe's stanza comprises three pentameters ( 2 hem x 3 ) and an adonic verse (as in the last line of a Sapphic stanza) which seems to be his own invention, not paralleled in Greek poetry. The striking feature of its prosody is the plenitude of hiatus, certo certius deliberate, to the number of thirteen, over the span of only four strophes. Especially illustrative is

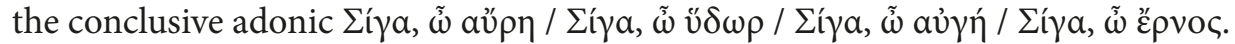

Derzhavin's verse is a free translation of the Italian poem Amor timido, by Metastasio (1698-1782), ${ }^{33}$ for which Derzhavin used a verbum pro verbo translation by Nicolay Lvov (1753-1803). Derzhavin also translated into Russian from Anacreontica, Anthologia Palatina and Sappho. It seems, then, that his Greek imitations sounded quite authentic to Graefe and inspired him to render Modesty into Ancient Greek, also stylized by Derzhavin as a poem from the Greek Anthology.

The inclusion of Derzhavin's Modesty in Ancient Greek translation proves that the manuscript was written in Russia; it should be admitted, nevertheless, that the verses from the manuscript could have been composed at different times.

\section{Commentary}

Probably, the title could have been influenced by Nonnus's Dionysiaca 33, 107: kaì

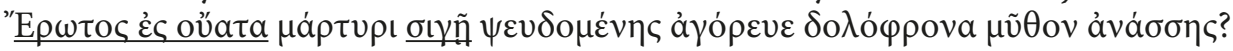

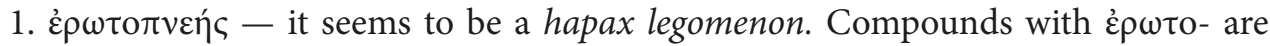
numerous (see LSJ) but compounds to - $\pi v \varepsilon \eta ́ \varsigma$ are rare, according to Kretschmer, ${ }^{34}$ there is only år

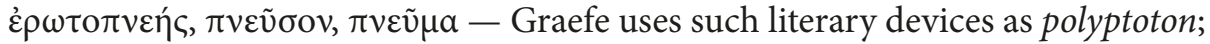

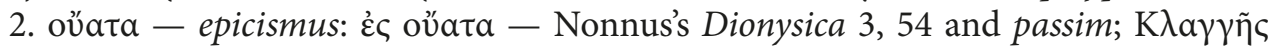

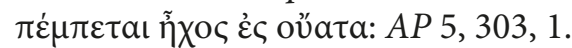

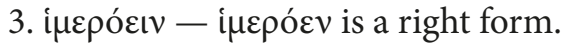

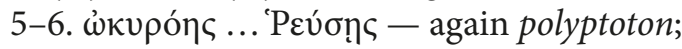

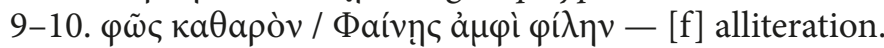

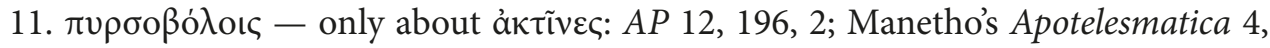
214, 438 .

Graefe's Greek version of Derzhavin is elegant and far from being a slavishly literal translation. The occurrence of lexica from AP and Nonnus's Dionysiaca, which was edited by Graefe, proves him to be their author.

Graefe was among the first German scholars to be active at the dawn of Russian classical scholarship. The tradition of versification in Ancient Greek in Russia, which seemed also to start with Graefe, includes such names as Fyodor Y. Korsch, ${ }^{35}$ Vyacheslav Ivanov, ${ }^{36}$ Salomo Luria, ${ }^{37}$ Iakob M. Borovsky, ${ }^{38}$ and Dmitry Y. Aphinogenov. ${ }^{39}$ The tradition of translation into Ancient Greek in Russia, on the other hand, is not as rich but includes Eugenius Bulgaris (from Vergil) and F. Y. Korsch (from Russian, German, Arabic, Persian,

${ }^{33}$ Placido zefiretto, / Se trovi il car oggetto / Digli che sei sospiro; / Ma non gli dir di chi, etc. See a commentary in Derzhavin 1986, 423.

${ }^{34}$ Kretschmer 1977, 232.

35 I name only authors whose Ancient Greek translations were published.

36 Ivanov 1912, 112-113.

37 Lurie, Polak 1994, 7. My thanks go to Leonid Zhmud for the reference to this article.

38 Borovsky 2009, 429; 448; 453.

39 Afinogenov 2010, 644-647. 
and Sanskrit). ${ }^{40}$ Graefe was thus a veritable force in composing Ancient Greek translations in the 19 th century.

\section{References}

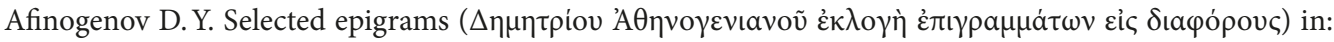
A. I. Solopov (ed.) NYMФ $\Omega$ N ANTPON. Acta philologorum 15. Collectanea in honorem Azae TachoGodi Alibeci $f$. Moscoviae, in aedibus NICAEI, 2010, 644-647.

Borovsky J.M. (Iacobus Marci filius Borovskij). Opera Philologica. Ed. by A.K. Gavrilov, T. V. Shaburina, V. V.Zelchenko. St. Petersburg, Dmitry Bulanin, 2009.

Bulgaris E. Opera Georgica et Aeneis graeco carmine heroico expressi / notisque perpetuis illustrati. Vol. 1-4. Petropolis, Typis Academiae Scientiarum, 1786-1792.

Bursia C. Gräfe, Christian Friedrich, in: Allgemeine Deutsche Biographie 1879, 9, 555-556, https://www. deutsche-biographie.de/sfz21923.html (16.12.2017).

Danilevskij R. Ju. Schiller in der russischen Literatur: 18. Jh. — erste Halfte 19. Jhs. Dresden, Univ. press, 1998.

Derzhavin G. Anakreonticheskiye pesni [Anacreontica]. Ed. by G. P. Makogonenko, G. N. Ionin, E. N. Petrova. Moskva, Nauka, 1986.

Gavrilov A. K. Arkhiyepiskop Evgeniy Bulgaris [Archbishop Eugenius Bulgaris], in: Id. O filologakh i filologii [On philologists and philology]. St. Peterburg, Univ. Press., 2010, 65-71.

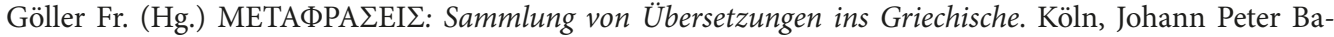
chem, 1825.

Graefe Fr. (ed.) Nonni Panopolitae Dionysiacorum libri XLVIII. Vol. 1-2. Leipzig, Vogel, 1819-1826.

Hermann G. Opuscula. Vol. 5. Lipsiae, apud Ernestum Fleischerum, 1834.

Ivanov V. Nezhnaja tajna [Soft secret]. St. Petersburg, "Ory”, 1912.

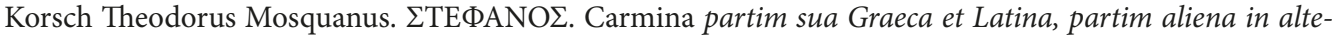
rutram linguam ab se conversa [...], Hauniae, Sumptibus Librariae Gyldendalianae (Hegeliorum patris et filii), 1886 [=Aristeas 2012, 6, 13-67].

Kretschmer P., Locker E. Rückläufiges Wörterbuch der griechischen Sprache. Göttingen, Vandenhoeck \& Ruprecht, 1977.

Lotman J. Neue Materialien über die Anfänge der Beschäftigung mit Schiller in der russischen Literatur. Wissenschaftliche Zeitschrift der Ernst Moritz Arndt-Universität Greifswald 1958/59, 8, 419-434.

Lurie J., Polak L. 'Sudba istorika v kontekste istorii (S. J. Lurie: zhisn' i tvorchestvo)' [The fate of historian at the context of history (S. J. Lurie: life and work)]. Journal for the History of Science. 1994, 2, 3-17.

Oldfather C. H. (tr.) Diodorus of Sicily in Twelve Volumes. 2. Cambridge (Mass.) - London, Harvard University Press, William Heinemann LTD, 1979.

Porson R. (Ed.) Euripides. Hecuba. Cambridge, CUP, 21802.

Richtsteig E. Deutsche Dichtungen in griechischem Gewande. Breslau, Trewendt \& Granier, 1927.

Saltzwedel J.(Hg.) Eckstein Fr. A. Nomenclator philologorum. [Erstausg. 1871]. Hamburg 2005, http://www. venturus.de/eckstein.pdf (20.04.2018).

Schiller Fr. Die Braut von Messina oder die feindlichen Brüder. Ein Trauerspiel mit Chören. Über den Gebrauch des Chors in der Tragödie. Tübingen, J. G. Gotta’schen Buchhandlung, 1803.

Schmid G. Zur russischen Gelehrten Geschichte. S. S. Uwarov und Christian Friedrich Graefe. Russische Revue 1886, 26, 77-108, 156-167.

Smyshlyayeva V.P. Rossiiskie filologi-klassiki XIX veka. "Germanovskoe napravlenie" [Russian Classical Philologists of XIX c. influenced by G. Hermann]. SPb., Lema, 2015.

Thiersch F. (Ed.) Anthologia carminum Graecorum. Acta Philologorum Monacensium 1820, III/1, 139-155.

Uvarov S. S. Vospomonaniya ob akademike F. Grefe. Uchenyye zapiski imperatorskoy akademii nauk po I i III otdeleniyam. I. 1. [A memoir about academician F. Graefe. The Scientific Notes of the Imperial Academy of Sciences for the I and III Departments]. SPb., 1852.

Verlinsky A. Philologia inter Disciplinas: The Department of Classics at St Petersburg University 1819-1884. Hyperboreus 2013, 19, 162-204.

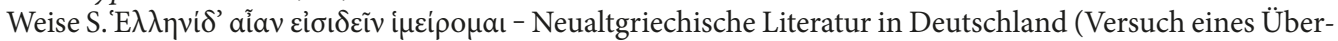
blicks). Antike \& Abendland 2016, 62, 114-181.

40 Bulgaris 1786; Korsch 1886; 2012, 13-67; about Bulgaris see: Gavrilov 2010, 65-71. 
Wilamowitz-Moellendorf U.von. Geschichte der Philologie. Stuttgart — Leipzig, Teubner, ${ }^{3} 1998$.

Wöhrle G. Goethes Erlkönig — altgriechisch. Philologia Classica 2016, 11 (1), 77-81.

Received: 04.01.2018

Final version received: 10.04 .2018

\section{Фридрих Шиллер и Гавриил Державин на греческом: переводы Христиана Фридриха Грефе (1780-1851)}

\section{Елена Леонидовна Ермолаева}

Санкт-Петербургский государственный университет,

Российская Федерация, 199034, Санкт-Петербург, Университетская наб., 7-9; e.ermolaeva@spbu.ru

Христиан Фридрих Грефе, служивший ординарным профессором кафедр греческой и латинской словесности Санкт-Петербургского университета со дня его основания (1819 г.) и до конца своей жизни (1851 г.), академик, помощник хранителя античной коллекции Эрмитажа, директор кабинетов антиков и медалей, учитель и друг графа С. С. Уварова, принадлежал к первому поколению учеников Готфрида Германа в Лейпциге. Следуя Герману, Грефе сочинял стихи на латинском и древнегреческом языках. В статье впервые напечатаны и снабжены комментарием переводы Грефе на древнегреческий - начало пролога Мессинской невесты Ф. Шиллера и стихотворение Скромность Г. Р. Державина. Следуя Герману, Грефе свободно говорил и сочинял стихи на латинском и древнегреческом языках. Список изданных латинских и греческих стихов (Gelegenheits-Schriften) Грефе был опубликован после его смерти в бюллетене Императорской академии наук за 1852 г. В отделе рукописей Российской национальной библиотеки в фонде И.В.Помяловского хранится рукопись Грефе с неизвестными прежде переводами из Шиллера и Державина, а также с неизданными греческими стихами, написанными элегическим дистихом, гексаметром и сапфической строфой, в подражание Солону, Сапфо и авторам Палатинской антологии; заключает эту своеобразную поэтическую антологию exhortatio в прозе, поучение, обращенное к некоему юноше. Поскольку рукопись никак не датируется и в ней отсутствует датировка стихов, автор предлагает версии того, когда и при каких обстоятельствах Грефе мог сделать переводы из пролога Шиллера и стихотворения Державина. Автор отмечает возможное влияние на Грефе греческих переводов Готфрида Германа из Валленштейна Шиллера и Франца Гёллера из пролога Мессинской невесты.

Ключевые слова: Грефе, Шиллер, Мессинская невеста, Державин, переводы на древнегреческий, Готфрид Герман. 